\title{
Impact of the acidic environment on gene expression and functional parameters of tumors in vitro and in vivo
}

Mandy Rauschner, Luisa Lange, Thea Hüsing, Sarah Reime, Alexander Nolze, Marcel Maschek, Oliver Thews and Anne Riemann ${ }^{*}$

\begin{abstract}
Background: The low extracellular $\mathrm{pH}\left(\mathrm{pH}_{\mathrm{e}}\right)$ of tumors resulting from glycolytic metabolism is a stress factor for the cells independent from concomitant hypoxia. The aim of the study was to analyze the impact of acidic $\mathrm{pH}_{\mathrm{e}}$ on gene expression on mRNA and protein level in two experimental tumor lines in vitro and in vivo and were compared to hypoxic conditions as well as combined acidosis+hypoxia.

Methods: Gene expression was analyzed in AT1 prostate and Walker-256 mammary carcinoma of the rat by Next Generation Sequencing (NGS), qPCR and Western blot. In addition, the impact of acidosis on tumor cell migration, adhesion, proliferation, cell death and mitochondrial activity was analyzed.

Results: NGS analyses revealed that 147 genes were uniformly regulated in both cell lines (in vitro) and 79 genes in both experimental tumors after $24 \mathrm{~h}$ at low pH. A subset of 25 genes was re-evaluated by qPCR and Western blot. Low pH consistently upregulated Aox1, Gls2, Gstp1, Ikbke, Per3, Pink1, Tlr5, Txnip, Ypel3 or downregulated Acat2, Brip1, Clspn, Dnajc25, Ercc6l, Mmd, Rif1, Zmpste24 whereas hypoxia alone led to a downregulation of most of the genes. Direct incubation at low pH reduced tumor cell adhesion whereas acidic pre-incubation increased the adhesive potential. In both tumor lines acidosis induced a G1-arrest (in vivo) of the cell cycle and a strong increase in necrotic cell death (but not in apoptosis). The mitochondrial $\mathrm{O}_{2}$ consumption increased gradually with decreasing $\mathrm{pH}$.

Conclusions: These data show that acidic $\mathrm{pH}_{\mathrm{e}}$ in tumors plays an important role for gene expression independently from hypoxia. In parallel, acidosis modulates functional properties of tumors relevant for their malignant potential and which might be the result of $\mathrm{pH}$-dependent gene expression.
\end{abstract}

Keywords: Acidosis, Hypoxia, Gene expression, Migration, Proliferation

\section{Background}

In comparison to healthy tissue many tumors show pronounced extracellular acidosis with $\mathrm{pH}$ values even below 6.0 [1]. These adverse environmental conditions result from increased glycolytic metabolism due to an insufficient oxygen supply. Thus, many tumors are characterized by concomitant hypoxia and extracellular

* Correspondence: anne.riemann@medizin.uni-halle.de Institute of Physiology, University Halle-Wittenberg, Magdeburger Str. 6, 06112 Halle (Saale), Germany

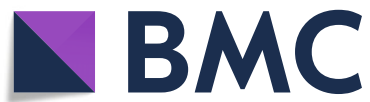

(c) The Author(s). 2020 Open Access This article is licensed under a Creative Commons Attribution 4.0 International License, which permits use, sharing, adaptation, distribution and reproduction in any medium or format, as long as you give appropriate credit to the original author(s) and the source, provide a link to the Creative Commons licence, and indicate if changes were made. The images or other third party material in this article are included in the article's Creative Commons licence, unless indicated otherwise in a credit line to the material. If material is not included in the article's Creative Commons licence and your intended use is not permitted by statutory regulation or exceeds the permitted use, you will need to obtain permission directly from the copyright holder. To view a copy of this licence, visit http://creativecommons.org/licenses/by/4.0/ The Creative Commons Public Domain Dedication waiver (http://creativecommons.org/publicdomain/zero/1.0/) applies to the data made available in this article, unless otherwise stated in a credit line to the data. 
Low extracellular $\mathrm{pH}\left(\mathrm{pH}_{\mathrm{e}}\right)$ has also been shown to modulate tumor cell function. Several studies revealed that acidosis increased the local invasiveness of tumors and the metastatic spread of tumors in vivo $[5,6]$. Tumor cells kept at low $\mathrm{pH}$ led to a significant higher number of lung metastases [7, 8]. Several mechanisms were discussed to be causative for the increased metastatic potential. Besides the induction of angiogenesis in acidotic tumors [9] or a $\mathrm{pH}$-dependent degradation of the extracellular matrix $[8,10]$ tumor cell migration is increased at moderately acid $\mathrm{pH}[7,11]$. Furthermore epithelial-to-mesenchymal transition (EMT) of cells has been shown to be modulated by acidosis $[12,13]$. Besides the metastatic spread, the sensitivity of tumors to non-surgical treatment modalities was found to be $\mathrm{pH}$ dependent. The efficacy of chemo- as well as of immunotherapy has been shown to be sensitive to an extracellular acidosis [14, 15]. Different mechanisms have been discussed by which the $\mathrm{H}^{+}$-level may affect the sensitivity, for instance, by affecting the drug permeability of the cell membrane [16], by the activation of active drug efflux pumps [17] or by acidosis-dependent changes of cytokine expression of tumor-associated immune cells $[16,18]$.

Many of these functional changes can be achieved by alterations of gene expression. For instance, it was shown that tumor cells change the expression of inflammatory cytokines (e.g., MCP-1, iNOS) at moderately low $\mathrm{pH}$ [19]. Also, the expression of matrix degrading enzymes (e.g., MMP-9) is acidosis-dependent [20]. However, most of these expression studies were performed only on a limited number of target genes and only the impact of isolated acidosis was analyzed. In tumors in vivo acidosis is always accompanied by a low $\mathrm{pO}_{2}$ (hypoxia) since the acidification results i.a. from the glycolytic metabolism induced by the $\mathrm{O}_{2}$ deficiency.

For these reasons, the aim of this study was to analyze the gene expression on the mRNA and protein level in two different tumor lines in isolated tumor cells under acidic or hypoxic conditions and during combined acidosis+hypoxia. These data were compared with in vivo expression results of experimental tumors (of the same tumor lines) in control tumors and in tumors in which a more pronounced tumor acidosis was induced either by forcing the glycolytic metabolism (inspiratory hypoxia + uncoupling the respiratory chain) or by intratumoral acid injection. In order to study the functional consequences of the altered expression functional parameters like proliferation, cell cycle distribution, apoptosis, necrosis, cell migration and cell adhesion were analyzed under the acidic conditions. Finally, the impact of extracellular acidosis on the activity of the different steps of the respiratory chain within the mitochondria was measured.

\section{Material and methods Cell lines}

All studies were performed with two tumor cell lines of the rat: (a) subline AT1 of the Dunning prostate carcinoma R3327 (CLS \# 500121, CLS GmbH, Eppelheim, Germany) and (b) Walker-256 mammary carcinoma (ATCC \# CCL-38, LGC Standards GmbH, Wesel, Germany). The AT1 subline was established from the R3327 Dunning carcinoma cell line which was discovered in a male Copenhagen rat. The AT1 line is a anaplastic tumor growing androgen-independently [21]. In vivo AT1 cells form undifferentiated, densely packed tumors (without glandular structures) with a volume doubling time during the exponential growing phase of about 2.2 days and low metastatic potential [21]. AT1 cells show strong adhesion to collagen IV, laminin and natural extracellular matrix leading to low invasive potential [22]. The cell population shows a high amount of aneuploidic cells which highly express adhesion markers like CD24, CD44, CD326 or cytokeratin 19 [23].

The Walker-256 cell line was developed from a spontaneous tumor in the mammary gland of a pregnant rat and has been described as a carcinosarcoma [24]. The cells are undifferentiated but from the morphological aspect two distinct cell types could be classified. However, it is unclear whether the morphological differences result from independent cell types or whether they result from a multipotential stem cell [24]. Walker-256 cells are rapidly dividing and are tumorigenic after subcutaneous injection. The resulting tumors are undifferentiated [25] and grow with a volume doubling time of about 1.7 days. In contrast to the AT1 tumor model, Walker-256 tumor cells are highly metastatic forming bone and brain metastases [25, 26] during which a active destruction of subendothelial matrix by metalloproteinases plays a role [27].

Both cell lines were cultured in RPMI medium supplemented with $10 \%$ fetal calf serum (FCS) and for Walker256 cells additionally with $10 \mathrm{mM} \mathrm{L}$-glutamine, $20 \mathrm{mM}$ HEPES, 7.5\% $\mathrm{NaHCO}_{3}$. For the experiments, cells were incubated under serum starvation for $24 \mathrm{~h}$ either in medium buffered with $\mathrm{NaHCO}_{3}, 10 \mathrm{mM}$ MES (morpholinoethanesulfonic acid) and $10 \mathrm{mM}$ HEPES, $\mathrm{pH}$ adjustment to $\mathrm{pH} 7.4$ or 6.6 with $1 \mathrm{~N} \mathrm{HCl}$. Normoxic culture conditions were obtained by incubating the cells with room air containing $5 \% \mathrm{CO}_{2}$. Hypoxic culture conditions were induced in a hypoxia chamber (HypoxyLab, Oxford Optronix, Oxford, UK) at $0.2 \% \mathrm{O}_{2}\left(\mathrm{pO}_{2}=1.5 \mathrm{mmHg}\right)$ and $5 \% \mathrm{CO}_{2}$. For analysis of mRNA and protein expression cells were harvested and lysed after $24 \mathrm{~h}$ incubation under the respective conditions.

\section{In vivo tumor models}

Solid tumors of AT-1 cells were induced in vivo in male Copenhagen rats (body weight 145-332 g) and Walker- 
256 tumors in Wistar rats (body weight 213-284 g), housed in the animal care facility of the University of Halle. All experiments had previously been approved by the regional animal ethics committee and were conducted in accordance with the German Law for Animal Protection and the UKCCCR Guidelines [28].

Solid tumors were induced by heterotopic injection of cell suspension $\left(6-8 \times 10^{6}\right.$ cells $/ 0.4 \mathrm{ml}$ isotonic saline) subcutaneously into the dorsum of the hind foot. Tumor volumes were determined by measuring the three orthogonal diameters with a caliper and with the formula: $\mathrm{V}=\mathrm{d}_{1} \cdot \mathrm{d}_{2} \cdot \mathrm{d}_{3} \cdot \pi / 6$. Tumors were investigated when they reached a volume of $0.35-1.50 \mathrm{ml}$.

In order to induce a more pronounced tumor acidosis in vivo, two different methods were used. Firstly, metabolic acidosis was induced by treating tumor-bearing animals with a combination of inspiratory hypoxia and meta-iodobenzylguanidine (MIBG) which forces glycolytic metabolism [29]. Therefore, animals received a MIBG injection $(20 \mathrm{mg} / \mathrm{kg}$ b.w., i.p. dissolved in isotonic saline) and were then housed in a hypoxic atmosphere containing $10 \% \mathrm{O}_{2}$ and $90 \% \mathrm{~N}_{2}$ for $24 \mathrm{~h}$. This procedure reduces the extracellular $\mathrm{pH}$ in AT1 tumors from $7.02 \pm$ 0.04 to $6.48 \pm 0.08$ and in Walker-256 tumors from $7.16 \pm 0.03$ to $6.65 \pm 0.07$ [30]. Animals housed in room air receiving only the solvent served as control. Secondly, tissue acidosis was intensified by direct intratumoral injection of lactic acid. Therefore, $50 \mu \mathrm{l}$ of $0.222 \mathrm{mM}$ lactic acid (in $\mathrm{H}_{2} \mathrm{O}$ ) were injected into the tumor tissue at a depth of $2-3 \mathrm{~mm}$. Treatment of the contralateral tumor with $50 \mu \mathrm{l}$ of $0.222 \mathrm{mM}$ sodium lactate served as intraindividual control.

After $24 \mathrm{~h}$ animals were sacrificed, tumors were surgically removed, minced and total RNA was extracted using TRIzol reagent (Thermo Fisher Scientific, Waltham, MA, USA), while protein was isolated by using CST cell lysis buffer (20 mM Tris- $\mathrm{HCl}$ (pH 7.5), $150 \mathrm{mM}$ $\mathrm{NaCl}, 1 \mathrm{mM}$ EDTA, $1 \mathrm{mM}$ EGTA, 1\% Triton, 2,5 mM sodium pyrophosphate, $1 \mathrm{mM}$ ß-glycerophosphate, 1 $\mathrm{mM} \mathrm{Na}_{3} \mathrm{VO}_{4}$, protease inhibitor cocktail).

\section{mRNA expression}

For mRNA expression analyses total RNA was isolated using TRIzol according to the manufacturer's instructions. mRNA expression in cells and tumors was assessed by Next Generation-Sequencing followed by validation of the expression using quantitative PCR. Sequencing was performed on an Illumina System by Novogene Co Ltd. (Hongkong), followed by a raw data quality check, adapter clipping, quality trimming and alignment against the rat genome (RGSC 6.0/rn6). Initial mapping was done with Bowtie2 followed by Tophat2 using Bowtie to align spliced reads. Finally counting was performed with featureCounts and genes were annotated with BiomaRt v93. Normalization and differential expression analysis were performed using DESeq2 and EdgeR. Samples for NGS were obtained from lysates of cells incubated under acidotic and control conditions as well as from samples of tumors with intensified glycolytic metabolism and controls of both tumor lines. For further analysis mRNAs were eliminated which show low abundance ( $\leq 10$ fragments per million FPM). Fig. S1 (Additional file 1) shows the number of genes fulfilling this criterion in each experimental group. For detectable mRNAs the expression ratio acidosis-to-control was calculated. An acidosis-induced regulation was defined if in cells the expression was up- or downregulated by a factor of 1.5 and in tumors by a factor of 1.75. In order to analyze whether the acidosis-regulated genes may play a relevant role for functional properties of tumor cells (e.g., proliferation rate, cell death, activation of signaling pathways) a gene ontology analysis was performed from the NGS results for those genes which were significantly consistently up- or down regulated in AT1 and Walker256 tumor cells or solid tumors in vivo after $24 \mathrm{~h}$ of extracellular acidosis. This analysis was performed using the PANTHER Classification System (Ver. 15) and the GO-slim Overrepresentation Test [31]. By this, ontologies (biological processes and molecular functions) were identified which were statistically significant overrepresented (with false discovery rate (FDR) correction).

From the complete list of pH-regulated genes 25 (Acat2, Aox1, App, Brip1, Calcoco1, Clspn, Crem, Dnajc25, Ercc6l, Fstl1, Fundc1, Gls2, Gstp1, Ikbke, Il6r, Lamp2, Ltbp2, Mmd, Per3, Pink1, Rif1, Tlr5, Txnip, Ypel3, Zmpste24) were selected which were consistently regulated either in both cell lines in vitro or in vivo and which have been described to in literature to play a relevant rule in the malignant progression of tumors. For qPCR validation $1 \mu \mathrm{g}$ RNA was subjected to reverse transcription with SuperScript II reverse transcriptase (Thermo Fisher Scientific, Waltham, MA, USA) and analyzed by qPCR using the Platinum SYBR Green qPCR Supermix (Thermo Fisher Scientific, Waltham, MA, USA). The obtained data were normalized against $18 S$ or Hprt1, which are suitable housekeeping genes for studying tumor acidosis [32], and were related to the respective control. Suppl. Tab. S1 shows the primers used.

\section{Western blot}

Western blotting was performed according to standard protocols. In brief, cells were lysed $(0.5 \mathrm{M}$ Tris- $\mathrm{HCl} \mathrm{pH}$ 6.8; $10 \%$ SDS; $10 \%$ 2-mercaptoethanol; $20 \%$ glycerol; $0.01 \%$ bromophenol blue), separated by sodium dodecyl sulfate polyacrylamide gel electrophoresis, and transferred to a nitrocellulose membrane. Subsequently, membranes were incubated with antibodies specific for CREM (\#PA5-29927, Invitrogen, Darmstadt, Germany), 
GLS2 (\#PA5-78475, Invitrogen), PER3 (\#PA5-40922, Invitrogen) and TXNIP (\#14715, Cell Signaling, Danvers MA, USA). The bound primary antibody was visualized by IRDye secondary antibodies (Licor Biosciences, Lincoln, NE, USA) with the imaging system Odyssey (Licor Biosciences, Lincoln, NE, USA). Quantitative analysis was performed with Image Studio Lite software (Licor Biosciences, Lincoln, NE, USA).

\section{Tumor cell migration}

The migratory speed of AT1 tumor cells was determined after $24 \mathrm{~h}$ incubation at $\mathrm{pH} 7.4$ or 6.6. For time lapse microscopy $6 \times 10^{5}$ cells were grown in $35 \mathrm{~mm}$-Petri dishes, incubated with the buffers at different $\mathrm{pH}$ and transferred to an incubation chamber (stage Top Incubator INU-KI-F1; Tokai Hit) of a Keyence BZ-8100E fluorescence microscope (Keyence, Osaka Japan). Cell migration was measured over a time interval of 100 min with imaging every $5 \mathrm{~min}$. Single cells were tracked in this series of 20 images and the averaged migratory speed (in $\mu \mathrm{m} / \mathrm{min}$ ) as well as the covered distance (in $\mu \mathrm{m}$ ) was determined. For the calculations ImageJ software (ibidi Chemotaxis and Migration Tool, Gräfelfing, Germany) was used.

\section{Wound closure assay}

Migration was also assessed by a wound closure assay (Scratch Assay) using an automated video analysis system (IncuCyte Scratch Wound Migration and Invasion Assay, Essen BioScience, Ann Arbor MI, USA). The experiments were performed in accordance to the manufacturer's instructions. In brief, AT1 cells were cultured in 96-well plates $\left(1 \times 10^{5}\right.$ cells/well). $24 \mathrm{~h}$ before the measurement medium was replaced to fresh medium ( $\mathrm{pH}$ 7.4) without FCS and after $18 \mathrm{~h}$ medium was replaced by buffer with the respective $\mathrm{pH}$ (7.4 or 6.6). After $3 \mathrm{~h}$ incubation a defined wound area was created using Essen 96-well WoundMaker and the 96-well plate was transferred to an incubator for $24 \mathrm{~h}$ in which the closure of the wound was followed by a video system. Wound width (in $\mu \mathrm{m}$ ) and the percentage of wound closure was calculated.

\section{Cell adhesion}

Cell adhesion was measured by continuous impedance measurements of monolayer cells (xCELLigence DP; OLS OMNI Life Science, Bremen, Germany) in accordance to the manufacturer's instructions. First, it was tested whether cells lose their adherence if they are exposed to low $\mathrm{pH}$. Therefore, cells were plated on 16-well plates for $48 \mathrm{~h}$ to establish a tight contact between cells and plate surface. Thereafter, medium was changed to $\mathrm{pH} 7.4$ or pH 6.6 and impedance was followed for $48 \mathrm{~h}$. In the second series it was tested whether priming the cells at low $\mathrm{pH}$ for $24 \mathrm{~h}$ will affect the ability to adhere on the surface. Therefore, cells were pre-incubated at $\mathrm{pH}$ 6.6 or 7.4 in normal petri dishes for $24 \mathrm{~h}$. Subsequently, cells were mechanically detached and the cell suspensions were then transferred to 16-well plates in which the impedance was measured during the next $48 \mathrm{~h}$.

\section{Cell cycle distribution and proliferation}

For analysis of DNA content and the fraction of actively DNA-synthesizing cells, cells were incubated with $5 \mu \mathrm{M}$ BrdU (Bromodeoxyuridine) for $1 \mathrm{~h}$. Cells were then fixed with $70 \%$ ethanol and stained with anti-BrdU-antibody or isotype control (BD Biosciences, San Jose, CA, USA) and secondary anti-mouse-FITC-antibody $(1: 100)$ (Rockland, Limerick, PA, USA). Additionally, cells were stained for $10 \mathrm{~min}$ with $50 \mu \mathrm{g} / \mathrm{ml}$ propidium iodide+ RNase to measure cell cycle distribution. For analyses of tumors, BrdU was dissolved in PBS and injected i.p. $(150 \mathrm{mg} / \mathrm{kg}$ body wt). After $120 \mathrm{~min}$, tumors were excised and mechanically disintegrated into a single cell suspension.

\section{Apoptosis and necrosis}

Caspase-dependent apoptosis was assessed by measuring the activity of the effector caspase- 3 as described previously. In brief, cells were lysed, centrifugated and the supernatant was incubated with DEVD-AFC. The fluorescence of the cleaved dye 7-amino-4-trifluoromethylcoumarin (AFC) was measured in a multiwell counter (Infinite, Tecan, Berlin, Germany). Protein content was determined with Pierce BCA protein assay (Thermo scientific, Waltham, MA, USA) using bovine serum albumin as standard. For measurements in tumor samples small tissue specimens were minced before lysis. Necrosis in cultured cells was measured by LDH release. LDH activity in media and in cell lysates was measured using standard protocol adapted to lower scale $(200 \mu \mathrm{l})$.

\section{Cellular oxygen consumption}

The Seahorse XFe96 analyzer (Agilent, Santa Clara CA, USA) was used to measure the oxygen consumption rate by following the decrease in dissolved oxygen in sealed wells of a 96-well plate. In order to analyze different steps of mitochondrial $\mathrm{O}_{2}$ metabolism different inhibitors of the respiratory chain were added (XF Cell Mito Stress Test Kit, Agilent). By adding oligomycin (inhibiting complex V ATP synthase) $\mathrm{O}_{2}$ use for ATP production can be calculated. Adding carbonyl cyanide4-(trifluoromethoxy) phenylhydrazone (FCCP; uncoupling oxygen consumption from ATP production) reveals the maximal respiration rate and rotenone + antimycin A incubation (inhibiting complexes I and III) leads to the non-mitochondrial $\mathrm{O}_{2}$ consumption. 


\section{Statistical analysis}

Results are expressed as means \pm SEM. Differences between groups were assessed by the two-tailed t-test for paired and unpaired samples. The significance level was set at $\alpha=5 \%$ for all comparisons.

\section{Results}

\section{mRNA and protein expression}

NGS analyses were performed in both tumor lines in cultured cells and in experimental tumors. Following the criteria mentioned above, 703 (AT1 cells), 1350 (AT1 tumors), 1184 (Walker-256 cells) and 1099 (Walker-256 tumors) genes were regulated, respectively, under acidotic conditions for $24 \mathrm{~h}$. In order to identify cell line independent effects further analyses were only performed on genes which were uniformly regulated (either up or down) in both cell lines (136 genes) or tumors entities (287 genes, Suppl. Fig. S1). From these genes a subset of 25 was selected which have been described in the literature to play a relevant role in the malignant progression of tumors (e.g., Crem, Fstl1, Txnip). Figure 1a shows the impact of acidosis on gene expression in cultured cells (measured by qPCR). Most of the genes were consistently regulated in both tumor cells lines either up or down (for comparison NGS results are shown in Suppl. Fig. S2). If the cells were kept $48 \mathrm{~h}$ under acidic conditions the mRNA changes were even more pronounced than after $24 \mathrm{~h}$ (Suppl. Fig. S3). For instance, Txnip expression in AT1 cells, which was increased by a factor of 4 after $24 \mathrm{~h}$, was almost 32-times higher after $48 \mathrm{~h}$.

In contrast to acidosis, hypoxia $\left(\mathrm{pO}_{2}=1.5 \mathrm{mmHg}\right)$ at normal $\mathrm{pH}$ significantly reduced the expression of almost all of these 25 genes in both cell lines (Fig. 1b). In order to analyze the situation which corresponds to the in vivo situation, expression in cells was also measured under the simultaneous combination of acidosis+hypoxia (Fig. 1c). For many genes, the overall effect of combined acidosis and hypoxia reflected an additive impact of both conditions. For instance, the expression of Tlr5 (toll like receptor 5) was increased by acidosis and significantly downregulated by hypoxia, the combination of both had almost no impact on the mRNA level (Fig. 1c). Protein expression analyses of the tumor relevant genes CREM GLS2, PER3 and TXNIP mostly showed a diametrical regulation compared to mRNA expression in both cell lines under acidotic conditions (Fig. 2). For example, GLS2 (glutaminase 2) protein was significantly upregulated in AT1 cells but slightly downregulated in Walker-256 cells even though mRNA expression was doubled in these cells (Fig. 1a). Only TXNIP expression increased at low $\mathrm{pH}$ on mRNA and protein level in both cell lines.

To assess the impact of extracellular acidification in solid tumors two different techniques were used.
Glycolytic metabolism was stimulated by inspiratory hypoxia and uncoupling the respiratory chain. Since not only the $\mathrm{pH}$ was lowered but also the tissue $\mathrm{pO}_{2}$ was reduced, these conditions were comparable to the cell experiments in which acidosis and hypoxia were combined (Fig. 1c). Figure 3a shows the results concerning mRNA expression. Most of the genes were downregulated in both tumor lines. Only Lamp2, Per3 and Txnip showed a significant increase in mRNA expression. On protein level TXNIP expression increased in both tumor lines after $24 \mathrm{~h}$ (Fig. 4a). As a second method to lower the tumor pH locally, a direct injection of small amounts of lactic acid was used and the results were compared to tumors in which the same amount of $\mathrm{Na}^{+}$-lactate was injected. Using this method mRNA expression of almost all genes was downregulated in both tumor entities (Fig. 3b), however, due to large inter-tumor variability these changes were not statistically significant. On the protein level (Fig. 4) only PER3 was upregulated in Walker-256 tumor.

Recent studies reported that tumor cells adapt to long-term acidosis. Exposing tumor cells to low $\mathrm{pH}$ for 4 weeks or longer induced changes in protein expression and functional properties [33-36]. In order to analyze whether the changes in gene expression described above are the result of a short-term acidification $(24 \mathrm{~h})$ or can also be found in tumor cells chronically adapted to low $\mathrm{pH}$, AT1 cells were kept for 11 passages (5 weeks) at $\mathrm{pH}$ 6.6. Thereafter gene expression was analyzed by NGS and compared to control conditions as well as to acutely acidotic tumor cells. In the first passages after changing to low $\mathrm{pH}$ medium, proliferation of the AT1 cells was markedly slowed down, but in the following passages the cell doubling became faster, however, not reaching the control level (Suppl. Fig. S7). After 5 weeks of acidosis the expression of a large number of genes was changed in AT1 cells. Compared to acute acidosis $(24 \mathrm{~h})$ the number of $\mathrm{pH}$-regulated genes was approximately 5 -times higher after 5 weeks (Suppl. Fig. S8A), 1631 genes were upregulated and 1598 genes were downregulated. A direct comparison of the genes of interest shown in Fig. 1 revealed that several genes were regulated uniformly after $24 \mathrm{~h}$ and 5 weeks, such as Fundc1, Gls2, Per3 or Tlr5 (Suppl. Fig. S8B). However, several genes showed an opposite regulation, such as Acat2, Brip1 or Ercc6l. Txnip for instance, which was found to be strongly upregulated after $24 \mathrm{~h}$ was almost not regulated after long-term acidosis adaptation.

Several genes found to be regulated by acidosis after $24 \mathrm{~h}$ has been described to affect functional parameter of tumor progression, such as proliferation (e.g., Gls2 [37]), cell death (e.g., Txnip, Gls2 [38, 39] tumor cell 
A acidosis

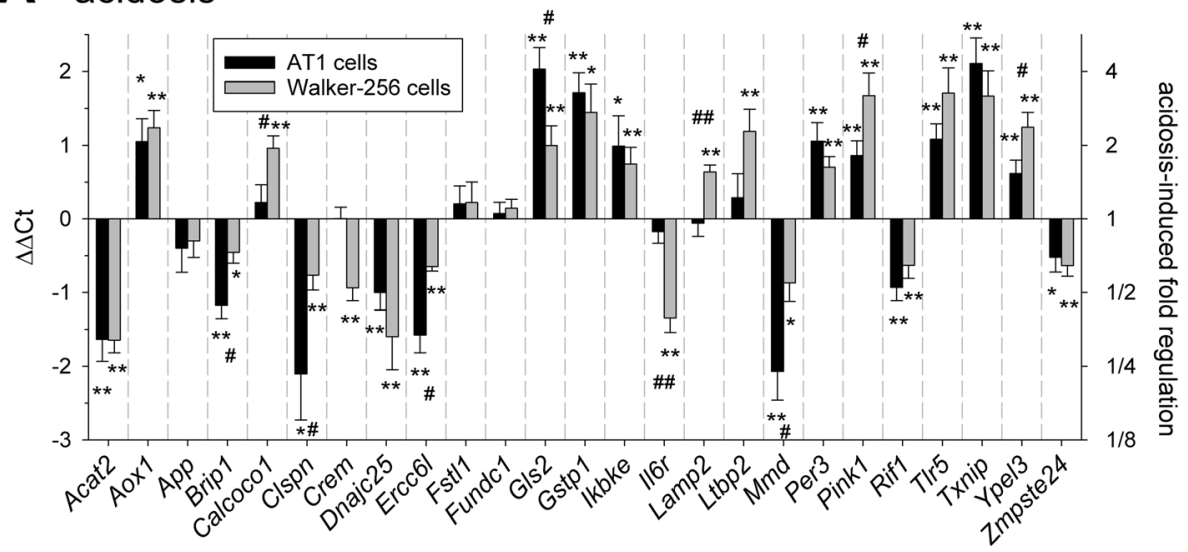

B hypoxia

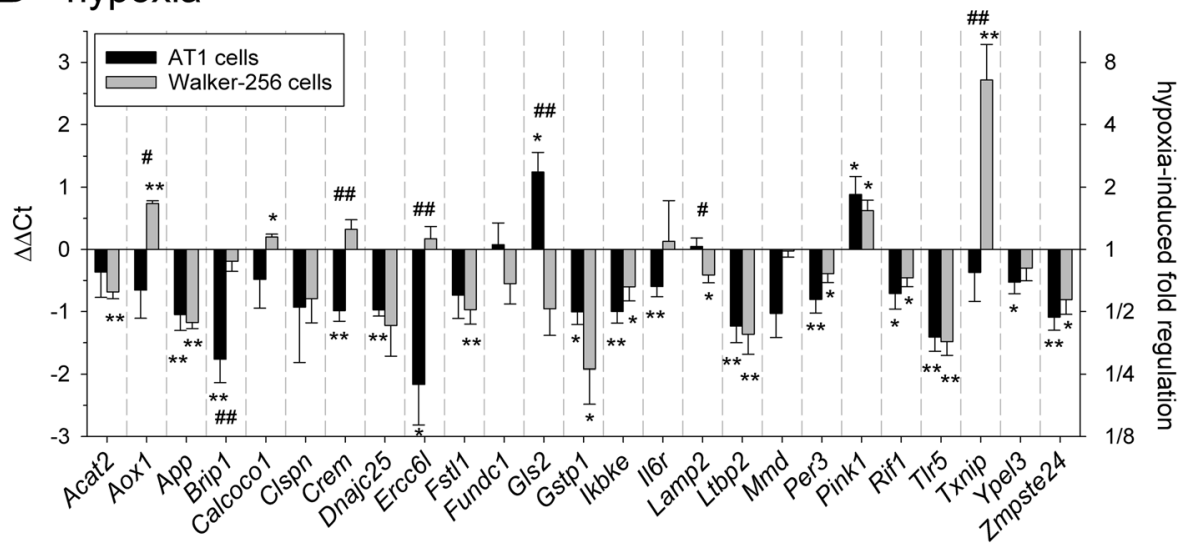

C acidosis + hypoxia

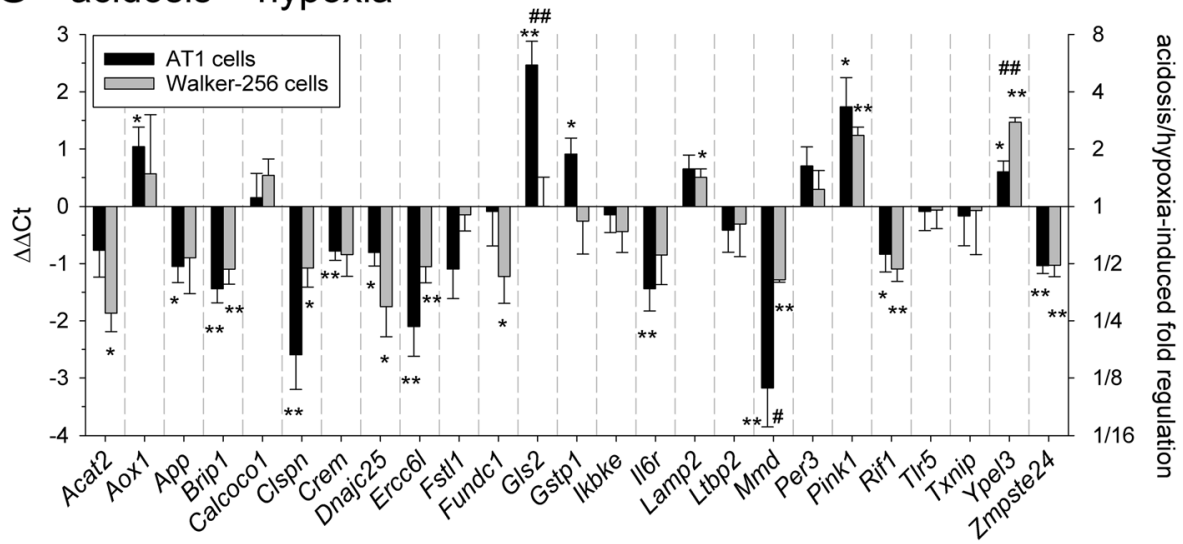

Fig. 1 mRNA expression of tumor-associated genes (measured by qPCR) in AT1 prostate and Walker-256 mammary carcinoma cells after $24 \mathrm{~h}$ under (a) acidotic ( $\mathrm{pH} 6.6$, room air), (b) hypoxic ( $\mathrm{pH} 7.4, \mathrm{pO}_{2}=1.5 \mathrm{mmHg}$ ) or (c) combined acidotic and hypoxic $\left(\mathrm{pH} 6.6, \mathrm{pO}_{2}=1.5 \mathrm{mmHg}\right) \mathrm{conditions} . n=4-$ $27 ;\left(^{*}\right) p<0.05,(* *) p<0.01$ vs. control; $\left(^{(*)} p<0.05,\left(^{* \#}\right) p<0.01\right.$ AT1 vs. Walker-256 cells

migration (e.g., Per3, Ikbke, Txnip [40-42] and adhesion (e.g., Txnip [43]) or mitochondrial activity (e.g., Txnip [44]). Therefore the impact of acidification on these cell functions was analyzed in the tumor models.

\section{Functional parameters}

The migratory speed of AT1 cells was $40 \%$ higher at $\mathrm{pH}$ 6.6 compared to control conditions (Fig. 5b, Suppl. Fig. S5B). In a scratch-assay with AT1 cells the wound width at pH 7.4 was $50 \%$ after 6 h (Fig. 5a, Suppl. Fig. S5A) 

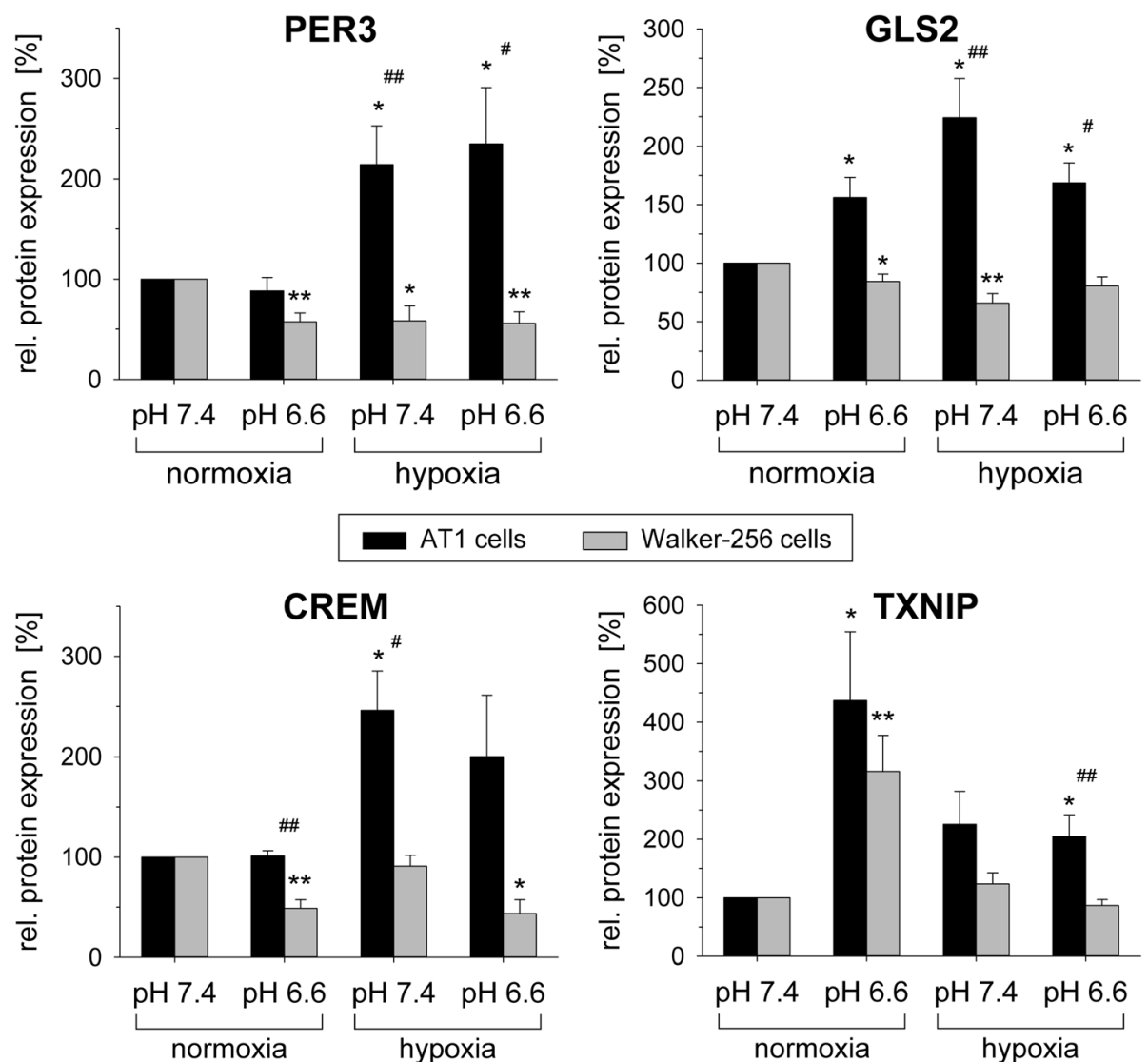

Walker-256 cells

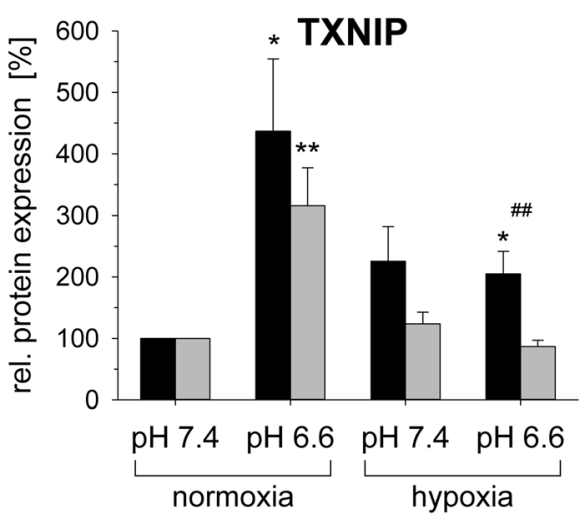

Fig. 2 Change of protein levels of PER3, GLS2, CREM and TXNIP in AT1 prostate and Walker-256 mammary carcinoma cells after $24 \mathrm{~h}$ under acidotic $\left(\mathrm{pH}\right.$ 6.6) and/or hypoxic $\left(\mathrm{pO}_{2}=1.5 \mathrm{mmHg}\right)$ conditions. $\mathrm{n}=4-12 ;\left(^{*}\right) \mathrm{p}<0.05,\left(^{* *}\right) p<0.01$ vs. control; $\left(\left(^{\#}\right) p<0.05,\left(\left(^{\#}\right) p<0.01\right.\right.$ AT1 vs. Walker-256 cells

whereas at $\mathrm{pH} 6.6$ the wound was closed by only $12 \%$. However, even the scratch assay was performed in serum-free medium, the results may also reflect the proliferative activity of the cells.

Cell adhesion of AT1 cells was measured by impedance technique. In order to For mimic the intratumoral acidic situation, adhesion was determined during incubation of cells at low pH. At pH 6.6 AT1 cell adhesion was strongly decreased whereas cells were progressively adherent at pH 7.4 (Fig. 5C1). For checking the metastatic potential of circulating tumor cells, cells were preincubated at low $\mathrm{pH}$, transferred to control $\mathrm{pH}$ and the adhesion was measured. In this setting cells incubated at pH 6.6 adhered much stronger than under control conditions (Fig. 5C2).

Tumor cell proliferation, measured by cell cycle analyses and $\mathrm{BrdU}$ incorporation, showed a $\mathrm{pH}$ dependent cell line-specific effect of acidosis. In AT1 cells a marked G1 arrest in the cell cycle was seen at pH 6.6, whereas in Walker-256 cells the cell cycle distribution was almost independent from the extracellular $\mathrm{pH}$ (Fig. 6a). The number of actively DNA synthesizing cells (BrdU- positive) was significantly lower at pH 6.6 in AT1 cells and slightly reduced in Walker-256 cells (Fig. 6b). In experimental tumors in vivo an acidification of the extracellular space by forcing glycolytic metabolism led to a significant increase of cells in the G0/G1 phase and a reduced number of $\mathrm{S}$ phase cells in both tumor models (Fig. 6c). In AT1 tumors proliferation was lower under acidic conditions whereas cell division of Walker-256 tumors, which show a much higher baseline proliferation than AT1 tumors, was independent from an additional acidification of the tissue (Fig. 6d).

Furthermore, the necrotic cell death was significantly increased at pH 6.6 (Fig. 7a) leading to a reduced number of surviving cells quantified by the amount of cellular protein (Fig. 7b). Caspase-dependent apoptosis was reduced by $30 \%$ at low pH only in Walker-256 cells but not in the AT1 cell line (Fig. 7c). In solid tumors in vivo this finding was reversed showing a 50\% reduction of apoptosis in AT1 tumors but not in Walker-256 tumors (Fig. 7d).

The analysis of cellular respiration showed a clear inverse relation of the baseline $\mathrm{O}_{2}$ consumption when lowering the extracellular $\mathrm{pH}$ (Suppl. Fig. S6). The $\mathrm{O}_{2}$ 


\section{A metabolic acidosis}

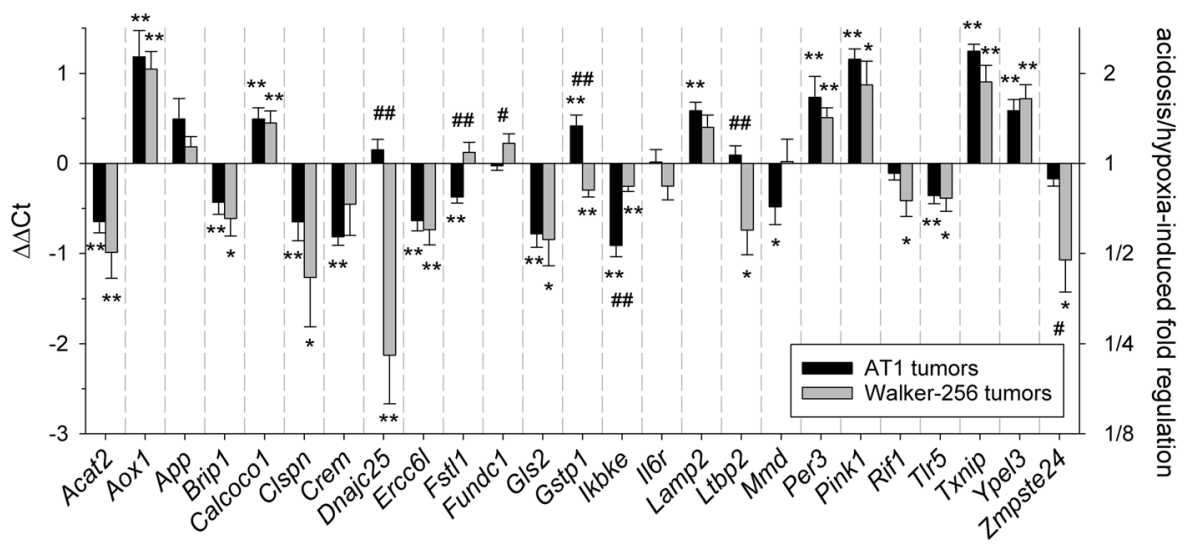

B acid application

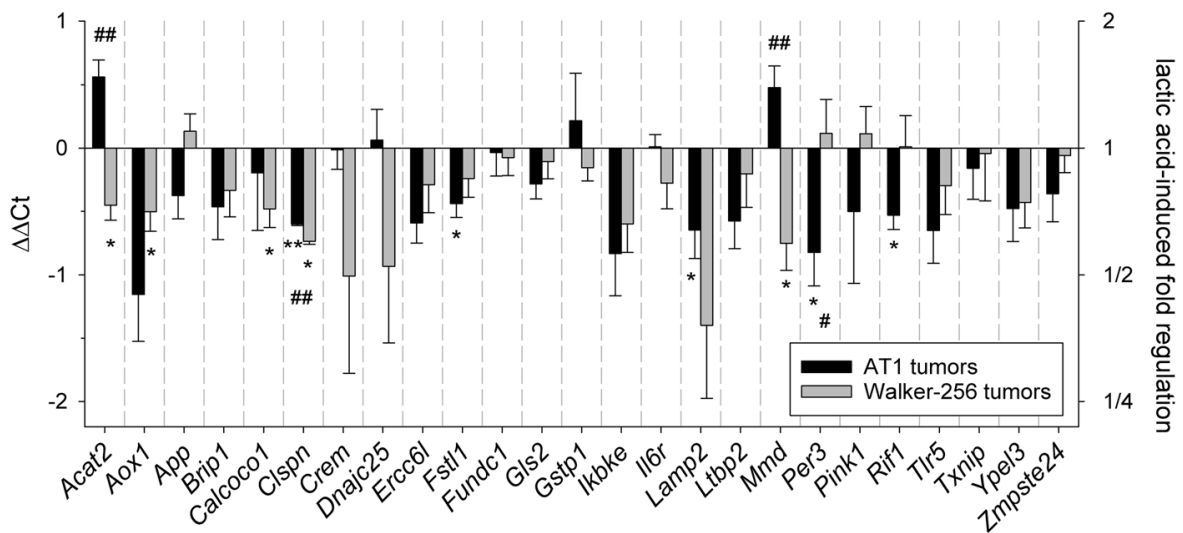

Fig. 3 mRNA expression of tumor-associated genes (measured by qPCR) in AT1 prostate and Walker-256 mammary carcinoma tumors in vivo 24 h after (a) inducing metabolic acidosis by forcing glycolytic metabolism or $(\mathbf{b})$ intratumoral injection of lactic acid. $n=4-22 ;\left(^{*}\right) p<0.05,\left(^{* *}\right) p<$ 0.01 vs. control; $\left(^{\#)} p<0.05\right.$, $\left(^{\# \#)} p<0.01\right.$ AT1 vs. Walker-256 tumors

consumption rate increased by $40 \%$ when $\mathrm{pH}_{\mathrm{e}}$ was reduced from 7.4 to 6.0. In normal rat kidney fibroblasts as a model of non-tumorous cells, oxygen consumption was independent from the $\mathrm{pH}$ (data not shown). The same $\mathrm{pH}$ dependency as seen for the baseline consumption (at least by trend) was found after inhibiting complex V ATP synthase (by oligomycin), after uncoupling oxygen consumption from ATP production (by FCCP) and after inhibiting complexes I and III (by rotenone + antimycin A). These results indicate that the mitochondrial $\mathrm{O}_{2}$ consumption as well as the non-mitochondrial $\mathrm{O}_{2}$ demand is $\mathrm{pH}$ dependent in tumor cells.

\section{Discussion}

In this study the impact of reduced extracellular $\mathrm{pH}$ in tumors on gene expression and function was analyzed. Since the aim was to find cell line-independent effects of tumor acidosis two different cell lines (AT1 prostate carcinoma and Walker-256 mammary carcinoma) were analyzed in vitro and in vivo and only consistent changes in the same direction may indicate generalized effects of an acidic tumor environment. Starting from a screening approach using NGS several genes were identified to be $\mathrm{pH}$-dependently regulated in both cell lines. In order to test whether these $\mathrm{pH}$ dependent genes may play a role for functional properties of tumor cells, such as proliferation, migration, cell adhesion or mitochondrial activity, a bioinformatic analysis (gene ontology overrepresentation test) was performed (Suppl. Tab. S2). It revealed that acidosis-dependent genes in AT1 or Walker-256 cells and/or tumors are associated with processes like DNA replication, DNA repair, response to cytokines, cell signaling (e.g., ERK1/2), metabolism or redox homeostasis which may play a role for the malignant potential of tumors. However, since many other aspects of the tumor cells (like differentiation, grade of malignancy etc.) may also be important for gene expression, it would also be interesting to analyze cell lines with the same genetic background but for 


\section{A metabolic acidosis}

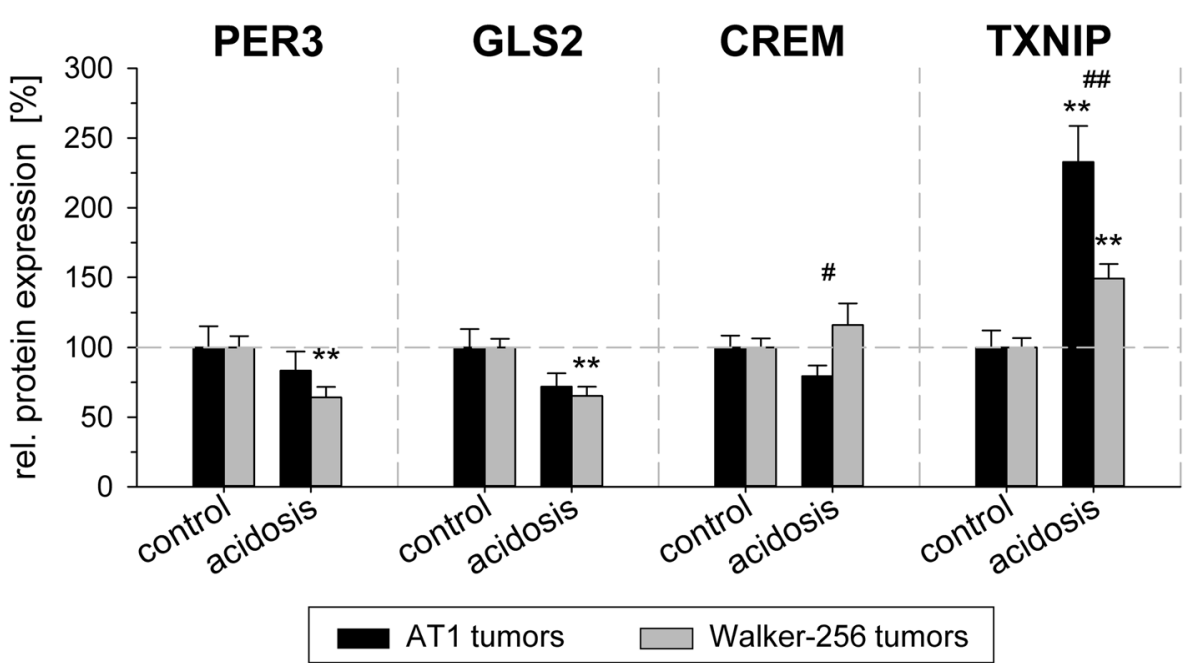

B acid application

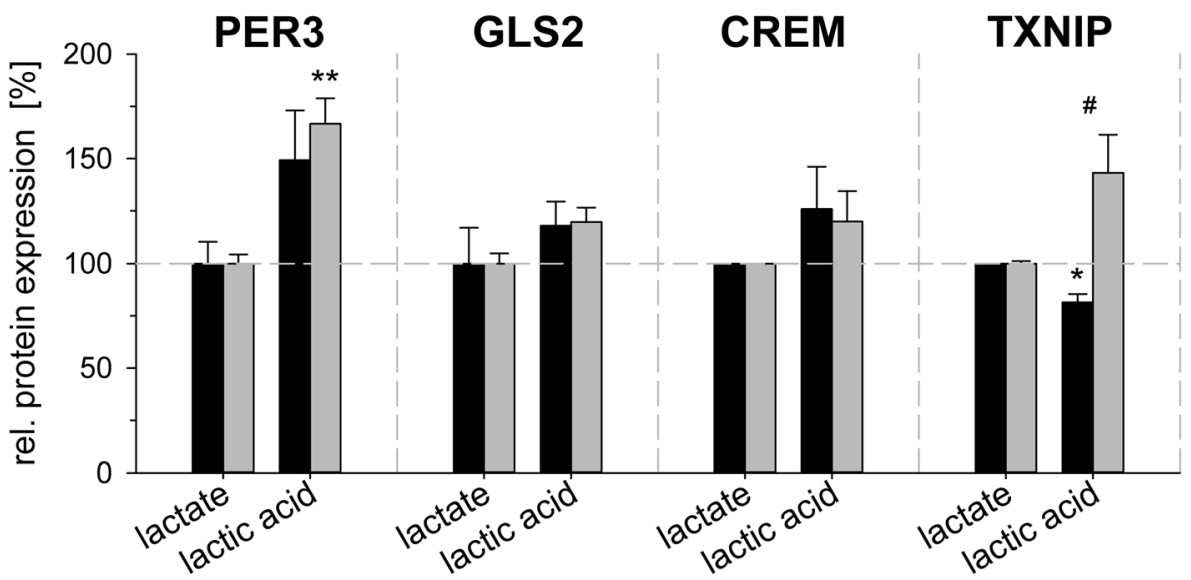

Fig. 4 Protein levels of PER3, GLS2, CREM and TXNIP in AT1 prostate and Walker-256 mammary carcinoma tumors in vivo $24 \mathrm{~h}$ after (a) inducing metabolic acidosis by forcing glycolytic metabolism or $(\mathbf{b})$ intratumoral injection of lactic acid. $n=4-18 ;\left(^{*}\right) p<0.05,\left(^{* *}\right) p<0.01$ vs. control; $\left(^{*}\right)$ $p<0.05,(\#) p<0.01$ AT1 vs. Walker-256 cells

instance different differentiation. This aspect has to be addressed in further studies.

For several genes found in the NGS analyses the pHdependent mRNA expression was confirmed by qPCR with upregulation of Txnip, Gls2, Aox1, Tlr5, Ikbke, Per3 and downregulation of Acat2, Dnajc25, Clspn, Mmd (Fig. 1a). The upregulation of these genes was not seen during hypoxia, however, the combination of acidosis+hypoxia indicated that upregulation resulted from the reduced $\mathrm{pH}$. In experimental tumors in vivo Txnip and Aox 1 were consistently upregulated in both models by low tissue $\mathrm{pH}$ due to intensified glycolytic metabolism. However, for interpretation of the in vivo results it should kept in mind that especially in AT1 tumors the tissue already shows pronounced hypoxia even under control conditions [45] which was further enhanced by inspiratory hypoxia. Thus, changes of protein expression may not only be induced by intensified tumor acidosis but also by low $\mathrm{pO}_{2}$. Therefore, in hypoxic AT1 tumors it might be more suitable to compare the in vivo tumor results with the cell results obtained under combined acidosis+hypoxia (Suppl. Fig. S4). In addition, since the measurements were performed in tumor tissue lysates, the data do not only result from tumor cells but also from other cells of the tumor matrix (e.g., fibroblasts or immune cells) which also change their gene and protein expression pattern by acidosis [13]. Taking the in vitro and in vivo results together, it was shown that Txnip, Aox1, Per3 and Ypel3 were consistently upregulated in both tumor lines and Acat2, Clspn and Ercc6l were downregulated. Lamp2 has been described to be overexpressed in aggressive tumors and 
A wound closure

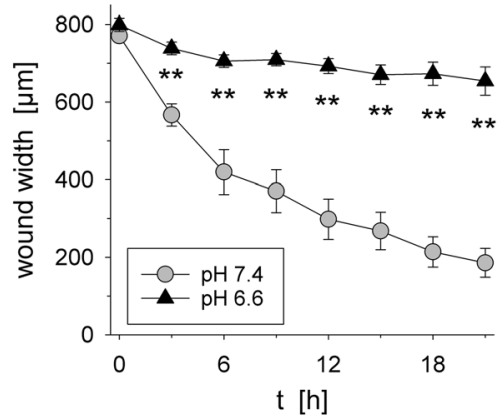

C1 cell adhesion: direct incubation

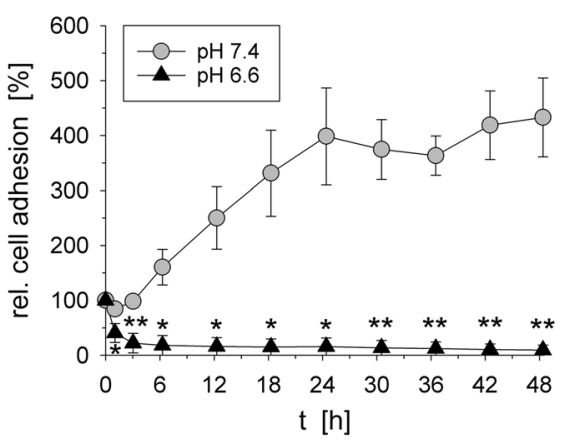

B cell migration

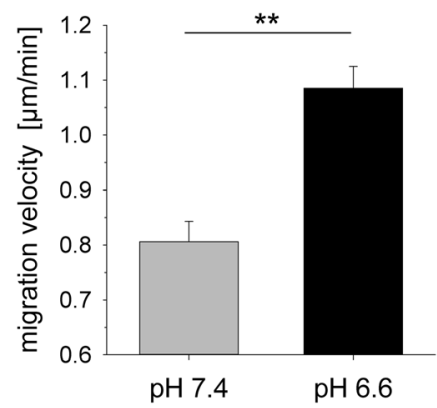

C2 cell adhesion: pre-incubation

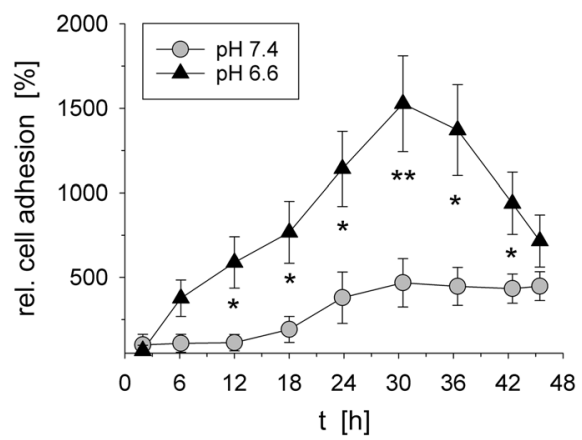

Fig. 5 (a) Wound closure determined by wound width (scratch assay; $n=15-16$ ) and (b) migration velocity (time lapse microscopy after $24 \mathrm{~h}$ incubation; $n=46$ ) of AT1 cells kept at pH 7.4 or. (c) Relative adhesion of AT1 cells up to $48 \mathrm{~h}$. Cells were analyzed either during continuous direct incubation at $\mathrm{pH} 6.6$ for $48 \mathrm{~h}$ ( $\mathbf{C 1}$ direct incubation; $n=3-4$ ) or after $24 \mathrm{~h}$ pre-incubation at $\mathrm{pH} 6.6$ after which the medium was changed to $\mathrm{pH}$ 7.4 for the following $48 \mathrm{~h}$ (C2 pre-incubation; $n=6) .\left(^{*}\right) \mathrm{p}<0.05$, (**) $\mathrm{p}<0.01$ vs. $\mathrm{pH} 7.4$

A cells: cell cycle distribution

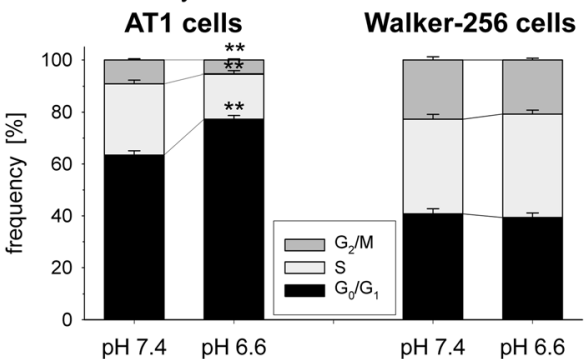

C tumors: cell cycle distribution
B cells: BrdU incorporation

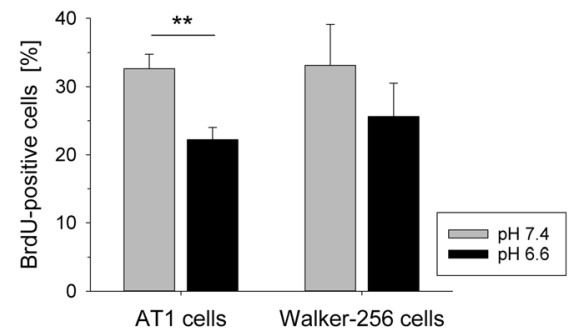

D tumors: BrdU incorporation
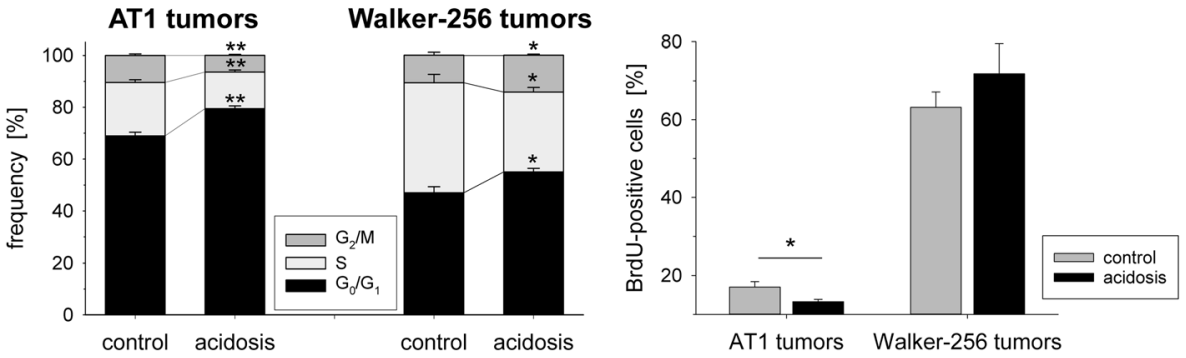

Fig. 6 Cell cycle distribution $(\mathbf{a}+\mathbf{c})$ and fraction of actively proliferating cells $(\mathbf{b}+\mathbf{d})$ in AT1 and Walker-256 cells in vitro $(\mathbf{a}+\mathbf{b})$ and AT1 and Walker-256 tumors in vivo $(\mathbf{c}+\mathbf{d})$ after $24 \mathrm{~h}$ under acidotic or control conditions. $n=6-37 ;\left(^{*}\right) p<0.05,\left(^{* *}\right) p<0.01$ acidosis vs. control 


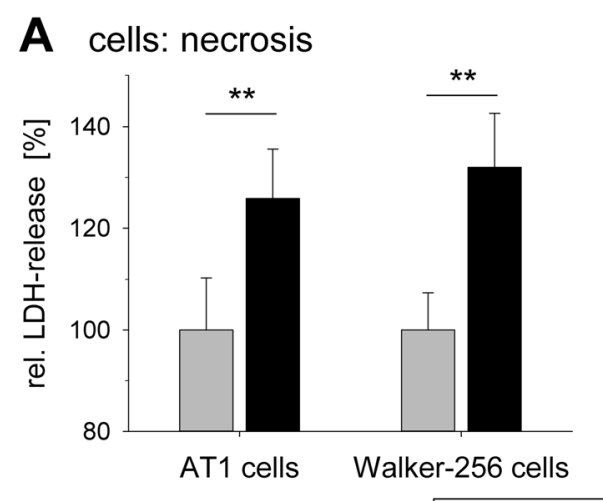

B cells: protein
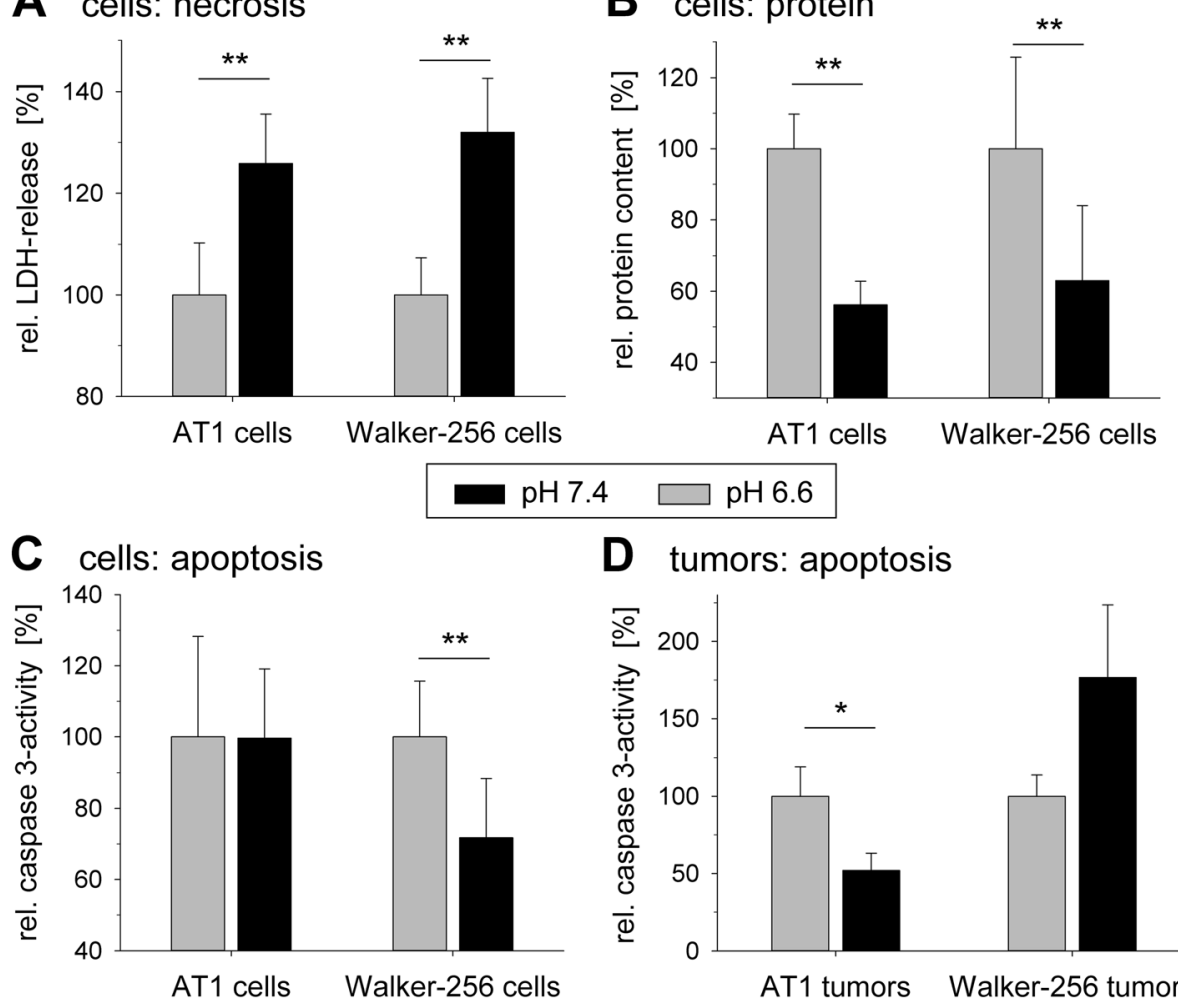

D tumors: apoptosis

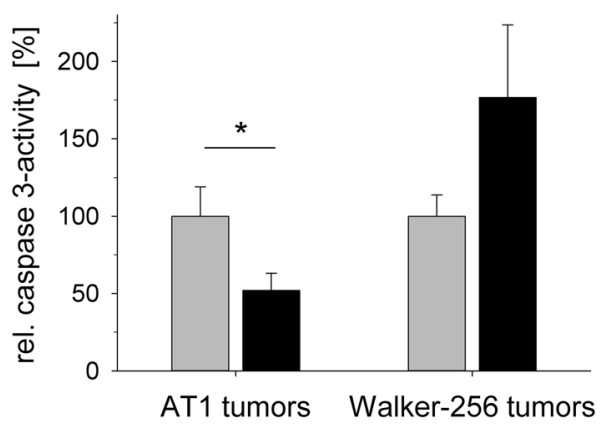

Fig. 7 (a) Necrosis (relative LDH release), (b) cell protein and (c) apoptosis (relative caspase-3 activity) of AT1 and Walker-256 cells in vitro after 24 $\mathrm{h}$ at pH 7.4 and 6.6. (d) Apoptosis in AT1 and Walker-256 tumors in vivo $24 \mathrm{~h}$ after inducing metabolic acidosis by intensifying glycolytic metabolism. $n=9-15 ;\left(^{*}\right) p<0.05$, (**) $p<0.01$ acidosis vs. control

to be upregulated in acidosis-adapted tumor cells [34]. This protein has been proposed as a histologic marker for pathologic correlation with in vivo $\mathrm{pH}_{\mathrm{e}}$ mapping [46]. However, in our study Lamp2 was found to be upregulated only in Walker-256 cells and in AT1 tumors (Figs. 1a and Fig. 3A). From these data it might be possible that acidosis-induced Lamp2 expression is cell line-specific and in solid tumors also affected by other cell types (e.g., fibroblasts). Also the duration of exposure to an acidic environment plays a role since in chronically acidosis-adapted AT1 cells an induction of Lamp2 expression was seen (Suppl. Fig. S8B).

$\mathrm{Xu}$ et al. [47] analyzed the expression of genes relevant for intracellular acid-base homeostasis in different tumor entities and detected numerous genes of $\mathrm{H}^{+}$-ATPases, MCT-, $\mathrm{HCO}_{3}{ }^{-}$- and NHE-transporters and some isoforms of the carbonic anhydrase to be upregulated in tumors. In our study we only found the V-ATPase gene Atp6v1c2 to be consistently upregulated upon low $\mathrm{pH}$ incubation. Additionally, acidosis-dependent changes of protein expression described for the AT1 cell line (e.g., NBC3, CRABP2) [48] were found in our study only in the prostate carcinoma cell line but not in the Walker-
256 mammary carcinoma line suggesting a cell linespecific response.

The most prominent acidosis-dependent changes in the expression were observed for Txnip, encoding the thioredoxin interacting protein (TXNIP), which was increased in both cell lines under in vitro and in vivo conditions. This protein is part of the redox system of tumors and inhibits cytosolic thioredoxin Trx-1 [49]. Since elevated levels of Trx-1 are associated with tumor progression the increase of TXNIP protein was associated with a higher overall survival of patients with mammary carcinomas [50] suggesting that TXNIP could inhibit tumor progression [49]. An increased Txnip expression with decreasing $\mathrm{pH}_{\mathrm{e}}$ has also been described by others $[39,51]$. High TXNIP levels were associated with a glycolytic phenotype of tumors [51] but also hypoxia downregulated TXNIP expression [52]. Obviously, the interaction of different environmental parameters plays an important role which is also seen in the present study, when cells were exposed to simultaneous acidosis+hypoxia leading to no changes in Txnip expression (Fig. 1C).

The situation becomes even more complex because acidosis induces the expression of genes which reduce 
the oxidative stress in tumors. GLS2, which is an important enzyme in conversion of glutamine to glutamate, and thereby a regulator of glutathione (GSH) synthesis [38], is upregulated in tumor cells at low pH (Figs. 1 and 2). Therefore, acidosis can either reduce the antioxidative capacity (e.g., via Txnip expression) or increase it (e.g., via Gls2 expression). In the present study in both cell lines low $\mathrm{pH}_{\mathrm{e}}$ led to an increased necrotic cell death (Fig. 7a, b) which may support the hypothesis of a reduced anti-oxidative capacity. One mechanism by which acidosis may induce the Gls2 expression is an upregulation of p53 [38]. Even though an increase of p53 at the mRNA level was not seen in our study, p53 might be involved on the function level. Since p53 is able to induce a G1 cell cycle arrest [53] the observed changes of the cell cycle distribution in both tumor lines (Fig. 6) could reflect a p53-dependent mechanism.

In an additional experiment the impact of long-term acidosis ( 5 weeks) was compared to acute changes after $24 \mathrm{~h}$ at low $\mathrm{pH}$ was analyzed. The comparison of acute and chronic changes revealed that several genes were regulated in the same direction, for instance Per3. Per3 expression was doubled not only after $24 \mathrm{~h}$ in both cell lines (Fig. 1a) but also after 5 weeks (Suppl. Fig. S8B). Therefore, Per3 seems to be an uniformly regulated gene during acute and chronic acidosis. Another gene, which has been described to be upregulated by long-term acidosis, is the carbonic anhydrase IX (Ca9) [54]. This was also seen in the present data, however in a timedependent degree. During acute acidosis $\mathrm{Ca} 9$ expression was increased by a factor of $2.6 \pm 0.5$ whereas after chronic adaptation the expression was higher by a factor of $4.2 \pm 0.1$. Finally, some genes were differentially regulated by acute or chronic acidosis. For instance, Lamp2 was not regulated after $24 \mathrm{~h}$ in AT1 cells (Fig. 1a) but was significantly upregulated in the same cell line after 5 weeks (Suppl. Fig. S8B) which is in accordance with results by others [34]. Since perfusion, and by this the oxygen supply of the tumor tissue, can vary in a time scale of minutes to hours [55], the impact of both short- and long-term $\mathrm{pH}$ changes on gene expression and function should be taken into account.

The results of the present study also clearly indicate that low extracellular $\mathrm{pH}$ strongly affects migration and cell adhesion of tumor cells (Fig. 5). These findings may also be related to the observed changes in gene expression. An increased expression of Per3 [40] or Ikbke [41] is associated with increased migratory potential. An elevated Txnip level has been shown to reduce the adhesion of tumor cells [43]. However, on the other hand elevated Txnip levels has been shown to inhibit migration [42]. The overall effect of extracellular acidosis on migration is difficult to predict. The results of the adhesion measurements in vitro (Fig. 5c) are in good accordance with previous in vivo experiments using the same AT1 tumor model, in which pre-conditioned tumor cells led to a higher number of lung metastases when injected i.v [7].

Measuring the cellular oxygen consumption clearly showed that in the AT1 tumor cells mitochondrial respiration increased with decreasing $\mathrm{pH}$ (Suppl. Fig. S6). Even under control condition AT1 cells show an almost maximal $\mathrm{O}_{2}$ consumption rate which could not be raised by collapsing the $\mathrm{H}^{+}$-gradient (incubation with FCCP). The baseline and the maximum $\mathrm{O}_{2}$ consumption increased almost linearly with decreasing $\mathrm{pH}$. ATP-linked respiration (oligomycin incubation) and non-mitochondrial $\mathrm{O}_{2}$ consumption increased only slightly at low $\mathrm{pH}$. Such a $\mathrm{pH}$ dependent increase of oxidative phosphorylation has also been described by others [56, 57]. However, some authors described a decrease of $\mathrm{O}_{2}$ consumption at pH 6.3-6.5 $[58,59]$. These contradictory results may be attributed to tumor cell-specific differences in the metabolic pathways (e.g., glycolysis, glutaminolysis, fatty acid metabolism) fueling the TCA [56]. The changes seen in the present study could be, at least partially, the results of the changed protein expression by acidosis. For cardiomyocytes it has been shown that a reduced TXNIP expression reduces the oxygen consumption rate [44] which would be in accordance to the present study.

\section{Conclusions}

In conclusion, our study demonstrates that the acidic extracellular $\mathrm{pH}$ in tumors plays an important role for gene expression independently from tissue hypoxia. In parallel, this study shows that acidosis affects several functional properties of tumors such as proliferation, cell cycle distribution, migration, or cell death and therefore for the malignant potential of tumors. Since several of the genes found to be $\mathrm{pH}$-dependent directly or indirectly interfere with the functional parameters studied, it can be hypothesized that acidosis modulates tumor cell function via $\mathrm{pH}$-dependent genes. However, this hypothesis of an causative link has to be addressed in further studies. The study also demonstrates that, with respect to gene expression, the results of cell culture experiments cannot be directly transferred to the in vivo situation were other cell types interfere with the tumor cells and form a micromilieu in which different metabolic parameters, cell-cell- or cell-matrix-contacts, cytokines or other paracrine factors play a relevant role.

\section{Supplementary Information}

The online version contains supplementary material available at https://doi. org/10.1186/s13046-020-01815-4.

Additional file 1. Additional material (tables and figures) is provided in the "Additional file 1". Tab. S1. Primers used for qPCR. Tab. S2. Gene ontology analysis for acidosis-regulated genes in cells and tumors. Fig. 
S1. Venn diagrams of genes regulated by acidosis. Fig. S2. Comparison of NGS results in vitro and in vivo. Fig. S3. mRNA expression after $48 \mathrm{~h}$ acidosis. Fig. S4. Comparison of the impact of acidosis in vitro and in vivo. Fig. S5. Wound closure and migration distance during acidosis. Fig. S6. Cellular oxygen consumption during acidosis. Fig. S7. Tumor cell proliferation during long-term acidosis. Fig. S8. Gene expression of tumor cells chronically adapted to acidosis. The raw data of the NGS analyses are available via: https://www.ncbi.nlm.nih.gov/geo/query/acc. cgi?acc $=$ GSE162705

\section{Abbreviations}

AA: Antimycin A; Acat2: Acetyl-CoA acetyltransferase 2; Aox1: Aldehyde oxidase 1; Brip1: BRCA1 interacting protein C-terminal helicase 1; Clspn: Claspin; Crem: CAMP responsive element modulator; Dnajc25: DnaJ heat shock protein family (Hsp40) member C25; Ercc6l: ERCC excision repair 6 like, spindle assembly checkpoint helicase; Gls2: Glutaminase 2; Gstp1: Glutathione S-transferase pi 1; Ikbke: Inhibitor of kappa light polypeptide gene enhancer in B-cells, kinase epsilon; Lamp2: Lysosomal associated membrane protein 2; MIBG: Meta-iodobenzylguanidine; Mmd: Monocyte to macrophage differentiation associated; Per3: Period circadian clock 3; Pink1: PTEN induced kinase 1; Rif1: Replication timing regulatory factor 1 ; Tlr5: Toll-like receptor 5; Txnip: Thioredoxin interacting protein; Ypel3: Yippee like 3; Zmpste24: Zinc metallopeptidase STE24

\section{Acknowledgements}

None.

\section{Authors' contributions}

$A R$, OT and MR designed the study. MR, LL, TH, SR, and MM performed the experiments. AR, AN and OT analyzed the data. AR, MR and OT wrote the manuscript. All authors read and approved the final manuscript.

\section{Funding}

This study was supported by the Deutsche Forschungsgemeinschaft DFG (grant TH 482/6-1) and the Dr. med. h.c. Erwin Braun Foundation, Basel, Switzerland. Open Access funding enabled and organized by Projekt DEAL.

\section{Availability of data and materials}

All data generated or analyzed during this study are included in this published article and it supplementary material file. The datasets used and/or analysed during the current study are available from the corresponding author on reasonable request.

\section{Ethics approval and consent to participate}

Animal experiments had been approved by the regional animal ethics committee (Ref.No.: 42502-2-1426 MLU).

\section{Consent for publication}

All authors on this paper are aware of and agree to the content of the manuscript and agree to be listed as authors.

\section{Competing interests}

The authors declare no competing conflicts of interests.

Received: 27 July 2020 Accepted: 13 December 2020

Published online: 06 January 2021

\section{References}

1. Vaupel P, Kallinowski F, Okunieff P. Blood flow, oxygen and nutrient supply, and metabolic microenvironment of human tumors: a review. Cancer Res. 1989;49:6449-65.

2. Corbet C, Feron O. Tumour acidosis: from the passenger to the driver's seat. Nat Rev Cancer. 2017;17(10):577-93.

3. Pastorekova S, Gillies RJ. The role of carbonic anhydrase IX in cancer development: links to hypoxia, acidosis, and beyond. Cancer Metastasis Rev. 2019;38(1-2):65-77.

4. Vander Heiden MG, Cantley LC, Thompson CB. Understanding the Warburg effect: the metabolic requirements of cell proliferation. Science. 2009; 324(5930):1029-33.
5. Gatenby RA, Gawlinski ET, Gmitro AF, Kaylor B, Gillies RJ. Acid-mediated tumor invasion: a multidisciplinary study. Cancer Res. 2006;66(10):5216-23.

6. Lora-Michiels M, Yu D, Sanders L, Poulson JM, Azuma C, Case B, et al. Extracellular pH and $\mathrm{P}-31$ magnetic resonance spectroscopic variables are related to outcome in canine soft tissue sarcomas treated with thermoradiotherapy. Clin Cancer Res. 2006;12(19):5733-40.

7. Riemann A, Schneider B, Gündel D, Stock C, Thews O, Gekle M. Acidic priming enhances metastatic potential of cancer cells. Pflugers Arch. 2014; 466(11):2127-38.

8. Rofstad EK, Mathiesen B, Kindem K, Galappathi K. Acidic extracellular pH promotes experimental metastasis of human melanoma cells in athymic nude mice. Cancer Res. 2006;66(13):6699-707.

9. Shi Q, Le X, Wang B, Abbruzzese JL, Xiong Q, He Y, et al. Regulation of vascular endothelial growth factor expression by acidosis in human cancer cells. Oncogene. 2001;20(28):3751-6.

10. Kato Y, Ozawa S, Tsukuda M, Kubota E, Miyazaki K, St-Pierre Y, et al. Acidic extracellular pH increases calcium influx-triggered phospholipase D activity along with acidic sphingomyelinase activation to induce matrix metalloproteinase-9 expression in mouse metastatic melanoma. FEBS J. 2007;274(12):3171-83.

11. Stock C, Gassner B, Hauck CR, Arnold H, Mally S, Eble JA, et al. Migration of human melanoma cells depends on extracellular $\mathrm{pH}$ and $\mathrm{Na}^{+} / \mathrm{H}^{+}$exchange. J Physiol. 2005;567(Pt 1):225-38.

12. Peppicelli $\mathrm{S}$, Bianchini $\mathrm{F}$, Torre $\mathrm{E}$, Calorini L. Contribution of acidic melanoma cells undergoing epithelial-to-mesenchymal transition to aggressiveness of non-acidic melanoma cells. Clin Exp Metastasis. 2014;31(4):423-33.

13. Riemann A, Rauschner M, Gießelmann M, Reime S, Haupt V, Thews O. Extracellular acidosis modulates the expression of epithelial-mesenchymal transition (EMT) markers and adhesion of epithelial and tumor cells. Neoplasia. 2019;21:450-8.

14. da Silva VP, Mesquita CB, Nunes JS, de Bem PB, Rados PV, Visioli F. Effects of extracellular acidity on resistance to chemotherapy treatment: a systematic review. Med Oncol. 2018;35(12):161.

15. Siska PJ, Singer K, Evert K, Renner K, Kreutz M. The immunological Warburg effect: can a metabolic-tumor-stroma score (MeTS) guide cancer immunotherapy? Immunol Rev. 2020;295(1):187-202.

16. Kolosenko I, Avnet S, Baldini N, Viklund J, De Milito A. Therapeutic implications of tumor interstitial acidification. Semin Cancer Biol. 2017;43:119-33.

17. Sauvant C, Nowak M, Wirth C, Schneider B, Riemann A, Gekle M, et al. Acidosis induces multi-drug resistance in rat prostate cancer cells (AT1) in vitro and in vivo by increasing the activity of the p-glycoprotein via activation of p38. Int J Cancer. 2008;123(11):2532-42.

18. Riemann A, Wußling H, Loppnow H, Fu H, Reime S, Thews O. Acidosis differently modulates the inflammatory program in monocytes and macrophages. Biochim Biophys Acta. 2016;1862(1):72-81.

19. Riemann A, Reime $S$, Thews $O$. Tumor acidosis and hypoxia differently modulate the inflammatory program: measurements in vitro and in vivo. Neoplasia. 2017:19(12):1033-42.

20. Kato $Y$, Lambert CA, Colige AC, Mineur P, Noel A, Frankenne F, et al. Acidic extracellular $\mathrm{pH}$ induces matrix metalloproteinase-9 expression in mouse metastatic melanoma cells through the phospholipase D-mitogen-activated protein kinase signaling. J Biol Chem. 2005;280(12):10938-44.

21. Isaacs JT, Isaacs WB, Feitz WF, Scheres J. Establishment and characterization of seven dunning rat prostatic cancer cell lines and their use in developing methods for predicting metastatic abilities of prostatic cancers. Prostate. 1986;9(3):261-81.

22. Donald CD, Montgomery DE, Emmett N, Cooke DB 3rd. Invasive potential and substrate dependence of attachment in the dunning R-3327 rat prostate adenocarcinoma model. Invasion Metastasis. 1998;18(4):165-75.

23. Glowa C, Peschke P, Karger CP, Hahn EW, Huber PE, Debus J, et al. Flow cytometric characterization of tumor subpopulations in three sublines of the dunning R3327 rat prostate tumor model. Prostate. 2013;73(15):1710-20.

24. Simpkins H, Lehman JM, Mazurkiewicz JE, Davis BH. A morphological and phenotypic analysis of Walker 256 cells. Cancer Res. 1991;51(4):1334-8.

25. Lewis KM, Harford-Wright E, Vink R, Ghabriel MN. Characterisation of Walker 256 breast carcinoma cells from two tumour cell banks as assessed using two models of secondary brain tumours. Cancer Cell Int. 2013;13(1):5.

26. Shenoy PA, Kuo A, Vetter I, Smith MT. The Walker 256 breast cancer cellinduced bone pain model in rats. Front Pharmacol. 2016;7:286.

27. Shaughnessy SG, Whaley M, Lafrenie RM, Orr FW. Walker 256 tumor cell degradation of extracellular matrices involves a latent gelatinase activated by reactive oxygen species. Arch Biochem Biophys. 1993;304(2):314-21. 
28. Workman P, Aboagye EO, Balkwill F, Balmain A, Bruder G, Chaplin DJ, et al. Guidelines for the welfare and use of animals in cancer research. $\mathrm{Br} J$ Cancer. 2010;102(11):1555-77.

29. Kalliomäki T, Hill RP. Effects of tumour acidification with glucose+MIBG on the spontaneous metastatic potential of two murine cell lines. $\mathrm{Br} J$ Cancer 2004;90(9):1842-9.

30. Riemann A, Reime $\mathrm{S}$, Thews $\mathrm{O}$. Acidic extracellular environment affects miRNA expression in tumors in vitro and in vivo. Int J Cancer. 2018;144(7): 1609-18.

31. Mi H, Muruganujan A, Ebert D, Huang X, Thomas PD. PANTHER version 14: more genomes, a new PANTHER GO-slim and improvements in enrichment analysis tools. Nucleic Acids Res. 2019;47(D1):D419-D26.

32. Lemma S, Avnet S, Meade MJ, Chano T, Baldini N. Validation of suitable housekeeping genes for the normalization of mRNA expression for studying tumor acidosis. Int J Mol Sci. 2018;19(10):2930.

33. Andreucci E, Peppicelli S, Ruzzolini J, Bianchini F, Biagioni A, Papucci L, et al. The acidic tumor microenvironment drives a stem-like phenotype in melanoma cells. J Mol Med (Berl). 2020;98(10):1431-46.

34. Damaghi M, Tafreshi NK, Lloyd MC, Sprung R, Estrella V, Wojtkowiak JW, et al. Chronic acidosis in the tumour microenvironment selects for overexpression of LAMP2 in the plasma membrane. Nat Commun. 2015; 6:8752.

35. Pellegrini P, Serviss JT, Lundback T, Bancaro N, Mazurkiewicz M, Kolosenko I, et al. A drug screening assay on cancer cells chronically adapted to acidosis. Cancer Cell Int. 2018;18:147.

36. Yao J, Czaplinska D, lalchina R, Schnipper J, Liu B, Sandelin A, et al. Cancer cell acid adaptation gene expression response is correlated to tumorspecific tissue expression profiles and patient survival. Cancers (Basel). 2020; 12(8):2183.

37. de la Oliva AR L, Campos-Sandoval JA, Gomez-Garcia MC, Cardona C, Martin-Rufian M, Sialana FJ, et al. Nuclear translocation of Glutaminase GLS2 in human cancer cells associates with proliferation arrest and differentiation. Sci Rep. 2020;10(1):2259.

38. Suzuki S, Tanaka T, Poyurovsky MV, Nagano H, Mayama T, Ohkubo S, et al. Phosphate-activated glutaminase (GLS2), a p53-inducible regulator of glutamine metabolism and reactive oxygen species. Proc Natl Acad Sci U S A. 2010;107(16):7461-6.

39. LaMonte G, Tang X, Chen JL, Wu J, Ding CK, Keenan MM, et al. Acidosis induces reprogramming of cellular metabolism to mitigate oxidative stress. Cancer Metab. 2013;1(1):23.

40. Zhou L, Yu Y, Sun S, Zhang T, Wang M. Cry 1 regulates the clock gene network and promotes proliferation and migration via the Akt/P53/P21 pathway in human osteosarcoma cells. J Cancer. 2018;9(14):2480-91.

41. Liu T, Gao XS, Xin Y. Identification of an IKBKE inhibitor with antitumor activity in cancer cells overexpressing IKBKE. Cytokine. 2019;116:78-87.

42. Zhang J, Tian X, Yin H, Xiao S, Yi S, Zhang Y, et al. TXNIP induced by MondoA, rather than ChREBP, suppresses cervical cancer cell proliferation, migration and invasion. J Biochem. 2019;167(4):371-7.

43. Gunes A, Bagirsakci E, Iscan E, Cakan-Akdogan G, Aykutlu U, Senturk S, et al. Thioredoxin interacting protein promotes invasion in hepatocellular carcinoma. Oncotarget. 2018;9(96):36849-66.

44. Yoshioka J, Chutkow WA, Lee S, Kim JB, Yan J, Tian R, et al. Deletion of thioredoxin-interacting protein in mice impairs mitochondrial function but protects the myocardium from ischemia-reperfusion injury. J Clin Invest. 2012;122(1):267-79.

45. Frank J, Gündel D, Drescher S, Thews O, Mäder K. Injectable LiNc-BuO loaded microspheres as in vivo EPR oxygen sensors after co-implantation with tumor cells. Free Radic Biol Med. 2015;89:741-9.

46. Savic LJ, Schobert IT, Peters D, Walsh JJ, Laage-Gaupp FM, Hamm CA, et al. Molecular imaging of extracellular tumor $\mathrm{pH}$ to reveal effects of Locoregional therapy on liver cancer microenvironment. Clin Cancer Res. 2020;26(2):428-38

47. Xu K, Mao X, Mehta M, Cui J, Zhang C, Mao F, et al. Elucidation of how cancer cells avoid acidosis through comparative transcriptomic data analysis. PLoS One. 2013;8(8):e71177.

48. Ihling $\mathrm{A}$, Ihling $\mathrm{CH}$, Sinz $\mathrm{A}$, Gekle $\mathrm{M}$. Acidosis-induced changes in proteome patterns of the prostate cancer-derived tumor cell line AT-1. J Proteome Res. 2015;14(9):3996-4004.

49. Jia JJ, Geng WS, Wang ZQ, Chen L, Zeng XS. The role of thioredoxin system in cancer: strategy for cancer therapy. Cancer Chemother Pharmacol. 2019; 84(3):453-70.
50. Miligy IM, Gorringe KL, Toss MS, Al-Kawaz AA, Simpson P, Diez-Rodriguez M, et al. Thioredoxin-interacting protein is an independent risk stratifier for breast ductal carcinoma in situ. Mod Pathol. 2018;31(12):1807-15.

51. Chen JL, Merl D, Peterson CW, Wu J, Liu PY, Yin H, et al. Lactic acidosis triggers starvation response with paradoxical induction of TXNIP through MondoA. PLoS Genet. 2010;6(9):e1001093.

52. Chai TF, Leck YC, He H, Yu FX, Luo Y, Hagen T. Hypoxia-inducible factor independent down-regulation of thioredoxin-interacting protein in hypoxia. FEBS Lett. 2011;585(3):492-8.

53. Chen JD. The cell-cycle arrest and apoptotic functions of p53 in tumor initiation and progression. Cold Spring Harb Perspect Med. 2016;6(3): a026104.

54. Andreucci E, Peppicelli S, Carta F, Brisotto G, Biscontin E, Ruzzolini J, et al. Carbonic anhydrase IX inhibition affects viability of cancer cells adapted to extracellular acidosis. J Mol Med (Berl). 2017:95(12):1341-53.

55. Bussink J, Kaanders JH, Rijken PF, Martindale CA, van der Kogel AJ. Multiparameter analysis of vasculature, perfusion and proliferation in human tumour xenografts. Br J Cancer. 1998;77(1):57-64

56. Corbet C, Feron O. Cancer cell metabolism and mitochondria: nutrient plasticity for TCA cycle fueling. Biochim Biophys Acta Rev Cancer. 2017; 1868(1):7-15.

57. Khacho M, Tarabay M, Patten D, Khacho P, MacLaurin JG, Guadagno J, et al. Acidosis overrides oxygen deprivation to maintain mitochondrial function and cell survival. Nat Commun. 2014;5:3550.

58. Hong SM, Lee YK, Park I, Kwon SM, Min S, Yoon G. Lactic acidosis caused by repressed lactate dehydrogenase subunit B expression down-regulates mitochondrial oxidative phosphorylation via the pyruvate dehydrogenase (PDH)-PDH kinase axis. J Biol Chem. 2019;294(19):7810-20.

59. Sorensen BS, Busk M, Overgaard J, Horsman MR, Alsner J. Simultaneous hypoxia and low extracellular pH suppress overall metabolic rate and protein synthesis in vitro. PLoS One. 2015;10(8):e0134955.

\section{Publisher's Note}

Springer Nature remains neutral with regard to jurisdictional claims in published maps and institutional affiliations.

\section{Ready to submit your research? Choose BMC and benefit from:}

- fast, convenient online submission

- thorough peer review by experienced researchers in your field

- rapid publication on acceptance

- support for research data, including large and complex data types

- gold Open Access which fosters wider collaboration and increased citations

- maximum visibility for your research: over $100 \mathrm{M}$ website views per year

At BMC, research is always in progress.

Learn more biomedcentral.com/submission 